\title{
Influence of NAA and coconut water with variation of soaking duration on the growth of yellow bamboo branch cutting
}

\author{
TIA SETIAWATI", AGINTA PUTRI REHULINA KELIAT, RULY BUDIONO, RUHYAT PARTASASMITA ${ }^{\natural,}$ \\ JOHAN ISKANDAR
}

Department of Biology, Faculty of Mathematics and Natural Sciences, Universitas Padjadjaran. Jl. Sukarno-Hatta Km 21, Jatinangor, Sumedang, 45363, West Java, Indonesia. `email: tia@unpad.ac.id; ${ }^{\vee v}$ rp2010rikkyo@gmail.com

Manuscript received: 10 July 2018. Revision accepted: 22 August 2018.

\begin{abstract}
Setiawati T, Keliat APR, Budiono R, Partasasmita R, Iskandar J. 2018. Influence of NAA and coconut water with variation of soaking duration on the growth of yellow bamboo branch cutting. Nusantara Bioscience 10: 178-182. Yellow bamboo (Bambusa vulgaris Schrad Ex. var. Striata) is one kind of bamboo used for industrial and household raw materials. Yellow bamboo propagation with branch cuttings has relatively low percentage of growth. To increase the growing success of yellow bamboo branch cuttings can be used growth regulators substance, such as NAA and coconut water. This study aimed to obtain the best combination of NAA and coconut water with the soaking duration in the growth of yellow bamboo branch cuttings. The study was conducted using Completely Randomized Design (CRD) of $6 \times 3$ factorial arrangement with five replications. The first factor was the combination of NAA and coconut water $(\mathrm{CW})$, which consisted of six levels, namely $100 \% \mathrm{CW}, 20 \% \mathrm{NAA}+80 \% \mathrm{CW}, 40 \% \mathrm{NAA}+60 \% \mathrm{CW}, 60 \% \mathrm{NAA}+40 \%$ $\mathrm{CW}, 80 \% \mathrm{NAA}+20 \% \mathrm{CW}$ and $100 \%$ NAA. The second factor was the soaking duration which consists of three levels, namely $12 \mathrm{~h}, 24$ $\mathrm{h}$, and $36 \mathrm{~h}$. Parameters observed included shoot emerging time, shoot number, shoot length, leaf area, root number and root length. The data obtained were analyzed using the Analysis of Variance (ANOVA) and Duncan's Multiple Range Test (DMRT) $\alpha=5 \%$. The results showed that the combination of $80 \% \mathrm{NAA}+20 \% \mathrm{CW}$ gave the best yellow bamboo branch cuttings growth with an average shoot length of $1.44 \mathrm{~cm}$, leaf area $41.29 \mathrm{~cm}^{2}$, root number 42.87 and root length $23.70 \mathrm{~cm}$. The interaction of $80 \%$ NAA $+20 \% \mathrm{CW}$ with soaking duration of $36 \mathrm{~h}$ resulted in average the fastest shoot emerging time of 2.02 days after planting.
\end{abstract}

Keywords: Branch cutting, coconut water, yellow bamboo, NAA

\section{INTRODUCTION}

Bamboo is a perennial wood grass that grows very fast and produces very high biomass. Bamboo can absorb carbon faster than other similar tree species that have rapid growth. Bamboo has many utilities, among others as a source of local economy, structural raw materials, animal feed and fiber source for papermaking, home industry and household purposes (Banik 1995; Devi 2013).

In most bamboo-producing Asian countries, there is a shortage of supply and in recent years there is a widening gap between supply and demand (Devi 2013). Overexploitation occurs with the increased harvesting of bamboo from the wild or rural environments (Banik 1995; Devi 2013). The demand for bamboo increases steadily due to its versatile usage (Goyal et al. 2010). Yellow bamboo is one of the bamboo species of 19 species or groups of species agreed by The International Network for Bamboo and Rattan (INBAR) which cooperate with the International Plant Genetic Resources Institute, as research material which is worthy to be focused and wider use (Banik 1995)

In general, bamboo propagation is done vegetatively through rhizomes, stem and branches cuttings. The benefits of bamboo propagation through branch cuttings are the high availability and ease of handling (Banik 1995; Kaushal et al. 2011; Bhol and Parida 2015). This method is ideal for bamboo species with thick-walled branches such as Bambusa spp. or Dendrocalumus spp. (Banik 1995; Islam et al. 2011). Adventive root formations are important in vegetative propagation through cuttings which often result in significant economic losses (Pandey et al. 2011; Ibironke 2016), so it takes rooting hormones to increase root growth. As for the statement of Tiwari and Das (2010) that to improve sprouting, rooting and the survival of stem cuttings, plant growth regulators can be used.

Hormones that aid in adventitious root growth is auxin, such as an Indolebutyric acid (IBA) and Naphthalene Acetic acid (NAA), both are the most widely used commercial synthetic auxin for promoting root formation on stem cuttings (Muller and Leyser 2011: Khudhur and Omer 2015). But synthetic rooting hormone is still relatively expensive so it takes alternative substances that are cheaper but effective in supporting the growth of root cuttings. Natural substances that have the ability to stimulate rooting of cuttings, as a source of hormones such as auxin (IAA/indole-3-acetic acid), cytokinin, and gibberellin can be found in coconut water (Yong 2009; Karunarathna and Harris 2016). Yong et al. (2013) state that coconut water contains cytokinin which helps stimulate root and shoot growth. The cytokinin found in coconut water support cell division, and along with other chemical components promotes plant growth (Muhammad et al. 2015). In addition, the duration of soaking cuttings in 
active substance should be considered to obtain optimal growth on cuttings. Ibironke (2016) reported that root initiation on Boungainvillea cuttings can be increased when soaked with indole -3-butyric acid or coconut water for 510 minutes. The coconut water treatment on cuttings have the significant effects in increase shoot length, the girth of shoots, number of leaves, dry and fresh weight of root and root length.

\section{MATERIALS AND METHODS}

The materials used in this research were coconut water (Cocos nucifera), yellow bamboo branch as cuttings material,. Research used an experimental method in greenhouse with Completely Randomized Design (CRD) two factors. The first factor was six concentration combination of NAA and coconut water (CW) i.e. $0 \%$ $\mathrm{NAA}+100 \% \mathrm{CW}, 20 \% \mathrm{NAA}+80 \% \mathrm{CW}, 40 \% \mathrm{NAA}+$ $60 \% \mathrm{CW}, 60 \% \mathrm{NAA}+40 \% \mathrm{CW}, 80 \% \mathrm{NAA}+20 \% \mathrm{CW}$ and $100 \% \mathrm{NAA}+0 \% \mathrm{CW}$. The second factor was three treatment of soaking duration, i.e., 12, 24 and 36 h. Each treatment was repeated five times.

Variations of NAA concentrations used were $20 \%$, $40 \%, 60 \%$, and $80 \%$, taken from a stock solution of NAA $500 \mathrm{ppm}$, then mixed with coconut water according to a predetermined combination. Each mixed solution (NAA + coconut water) was prepared as much as $1000 \mathrm{~mL}$. The combination of NAA $20 \%+80 \% \mathrm{CW}$ was done by mixing $200 \mathrm{~mL}$ of NAA $500 \mathrm{ppm}$ with $800 \mathrm{~mL} \mathrm{CW}$, for other combinations were done in the same way. The branch was cut off the end so that the length of the cuttings was \pm 75 $\mathrm{cm}$ with 4 segments. The base of the bamboo branch was soaked in each treatment solution with different soaking periods i.e. 12,24 , and $36 \mathrm{~h}$. Branch cuttings were grown on mixed media of soil, sand, and manure (2:1:1) in polybag with vertical position.

Observations were made at 60 days after planting on buds emergence time, number and length of the shoot, leaf area, and number and length of the root. The data were statistically analyzed using SPSS 16.0. Analysis of variance (ANOVA) was performed to determine significant differences. Mean separation was carried out by the Duncan's Multiple Range Test (DMRT) $\alpha=5 \%$.

\section{RESULTS AND DISCUSSION}

The effect of NAA + coconut water combinations and soaking duration on the growth of branch cuttings. Table 1 showed that the combination of NAA $+\mathrm{CW}$, the duration of soaking and its interaction had no significant effect on the number of shoots, but had significant effect on the emergence time of shoot. The shoot length and leaf area were significantly affected by the combination of NAA + $\mathrm{CW}$. In root growth, the combination of NAA + CW had significant effect on number and length of root. There was no interaction effect on root growth.

\section{Emergence time of shoot and shoot number}

Based on the result of DMRT, the effect of NAA+ CW combination and soaking duration on emergence time and number of shoot on branch cutting. Table 2 showed that in the combination of $80 \% \mathrm{NAA}+20 \% \mathrm{CW}$ with soaking duration of 36 hours generated the fastest emerging time of bud was 2.02 days after planting and the highest shoot number was 2.05. In this treatment, it was suspected that NAA and plant growth regulator (PGR) contained in coconut water can be effectively translocated to the plant part that became the point of bud initiation. It was seen that in all combinations with longer soaking duration, the average time of shoot appears was faster and the number of shoot was also higher.

In general, the time of shoot emergence was faster and more shoots produced with increasing the duration of soaking. Soaking for $36 \mathrm{~h}$ allowed the increase of hormone solution absorbed by the cuttings, otherwise on 12 hours, PGR absorbed was not able to spur the growth of cuttings to the maximum. It seems the soaking duration is related to the amount of nutrients and PGR absorbed by the cuttings. Soaking will determine the length of contact time of the material to the solution so that it will affect the number of solutions absorbed by the plant which will ultimately affect the effectiveness of PGR (Islam et al. 2011; Razvi et al. 2011). Therefore the duration of soaking should be adjusted to the concentration of solution used.

Table 1. The ANOVA results of NAA + coconut water combinations and soaking duration effect on growth traits of yellow bamboo branch cuttings.

\begin{tabular}{lccc}
\hline Parameters & $\begin{array}{c}\text { Combination } \\
\text { of NAA }+ \\
\text { CW }(\mathbf{C})\end{array}$ & $\begin{array}{c}\text { Soaking } \\
\text { duration } \\
(\mathbf{T})\end{array}$ & $\begin{array}{c}\text { Interaction } \\
\text { of } \mathbf{C} \times \mathbf{T}\end{array}$ \\
\hline Emergence time of shoot & $*$ & $*$ & $*$ \\
Leaf area & $*$ & $\mathrm{~ns}$ & $\mathrm{~ns}$ \\
Length of root & $*$ & $\mathrm{~ns}$ & $\mathrm{~ns}$ \\
Length of shoot & $*$ & $\mathrm{~ns}$ & $\mathrm{~ns}$ \\
Number of root & $*$ & $\mathrm{~ns}$ & $\mathrm{~ns}$ \\
Number of shoot & $\mathrm{ns}$ & $\mathrm{ns}$ & $\mathrm{ns}$ \\
\hline
\end{tabular}

Note: * significant; $\mathrm{ns}=$ non significant

Table 2. The average emergence time of shoot and shoot number of branch cutting on the various combination of NAA + CW and soaking duration

\begin{tabular}{lcccccc}
\hline \multirow{2}{*}{$\begin{array}{l}\text { Combination of } \\
\text { NAA + CW }\end{array}$} & \multicolumn{3}{c}{$\begin{array}{c}\text { Emergence time of } \\
\text { shoot (hour) }\end{array}$} & \multicolumn{3}{c}{ Number of shoot } \\
\cline { 2 - 7 } & $\mathbf{1 2} \mathbf{~ h}$ & $\mathbf{2 4} \mathbf{~ h}$ & $\mathbf{3 6} \mathbf{~ h}$ & $\mathbf{1 2 ~ h}$ & $\mathbf{2 4} \mathbf{~ h}$ & $\mathbf{3 6 ~ h}$ \\
\hline $100 \% \mathrm{CW}$ & $6.80 \mathrm{~d}$ & $3.00 \mathrm{~b}$ & $2.65 \mathrm{ab}$ & 0.53 & 1.05 & 1.50 \\
$20 \% \mathrm{NAA}+80 \% \mathrm{CW}$ & $7.35 \mathrm{de}$ & $4.90 \mathrm{bc}$ & $2.45 \mathrm{ab}$ & 0.85 & 1.20 & 1.10 \\
$40 \% \mathrm{NAA}+60 \% \mathrm{CW}$ & $6.20 \mathrm{~d}$ & $3.30 \mathrm{~b}$ & $2.30 \mathrm{ab}$ & 0.70 & 0.75 & 1.35 \\
$60 \% \mathrm{NAA}+40 \% \mathrm{CW}$ & $4.90 \mathrm{bc}$ & $4.95 \mathrm{bc}$ & $2.30 \mathrm{ab}$ & 0.75 & 1.20 & 1.40 \\
$80 \% \mathrm{NAA}+20 \% \mathrm{CW}$ & $6.70 \mathrm{~d}$ & $4.75 \mathrm{bc}$ & $2.02 \mathrm{a}$ & 1.00 & 1.95 & 2.05 \\
$100 \% \mathrm{NAA}$ & $6.20 \mathrm{~d}$ & $4.80 \mathrm{bc}$ & $2.70 \mathrm{ab}$ & 0.70 & 1.10 & 1.55 \\
\hline
\end{tabular}

Note: the mean followed by the same letters on the same column showed no significant difference according to DMRT 5\%. 
In this study, the lowest coconut water concentration, i.e., $20 \%$ was able to induce shoots faster with the highest number. According to Davies (1990) plant hormones are organic substances which influence physiological processes at low concentrations. The formation of shoots with coconut water treatment in this study may be due to the presence of cytokinin that has major role in cell division, shoot formation, and activity of shoot meristem (Yong et al. 2009). The presence of cytokinin as reported by Davies (1990) may induce bud formation and the release of lateral buds from apical dominance. At $20 \%$ coconut water concentration, the need for cytokinin to induce buds, not only from exogenous cytokinin, but also endogenous cytokinin that is naturally produced by cuttings. Both will interact to produce physiological responses such as shoot formation. Wroblewska (2015) stated that the growth and development of plant are influenced by the interaction and balance between exogenous and endogenous hormones.

In addition, the application of NAA in this study contributes to shoot formation. According to Tiwari and Das (2010), the use of hormones or auxins plays an important role in affecting growth/sprouting and survival of stem cuttings. The formation of shoots/leaves can also be associated with rooting system. Nasri et al. (2015) suggested that increased production of new leaves in cuttings may be associated with an increase in the number and length of roots in auxin (IBA)-treated cuttings allowing cuttings to absorb more water and nutrients from rooting media, which in turn will contribute to better growth and new leaves formation. In all treatments of $\mathrm{CW}$-combined NAA showed higher root number than treatment without NAA.

\section{Length of shoot and leaf area of branch cutting}

Based on the result of DMRT, the effect of NAA+ CW combination on length of shoot and leaf area of branch cutting. Table 3 indicated that the highest average shoot length of $1.44 \mathrm{~cm}$ was found in the combination of $80 \%$ $\mathrm{NAA}+20 \% \mathrm{CW}$, significantly different from the other combinations. In this combination, the effect of cytokinin hormone contained in the coconut water allowed initiate the formation of buds more quickly (Table 2), so the shoot growth will also be faster and allowed longer buds to be produced. This condition can not be separated also from the contribution of auxin in elongation of cells and cytokinin in cell division so that buds become longer.

In the combination of $80 \% \mathrm{NAA}+20 \% \mathrm{CW}$ has also generated the highest average leaf area of $41.29 \mathrm{~cm}^{2}$ that was significantly different from other combinations. In this treatment, endogenous auxin (NAA) and cytokinin hormones in coconut water were sufficient for branch cuttings to promote cell division and differentiation in forming new shoots, so that no more exogenous hormones were required in high concentrations. The leaf area is the result of cell enlargement induced by the presence of cytokinin and related to the root growth. The total leaf area is adjusted to compensate for the extent of root growth, as the amount of cytokinin reaching the shoot will reflect the extent of the root system (Davies 1990).
In Table 3, 100\% NAA treatment lead in the growth and development restriction of shoot and leaf expansion. Similar results were found in a study by Rahdari et al. (2014) that on treated stem cutting of Cordyline terminalis with increased NAA concentrations from 1000 to 2000 and $3000 \mathrm{ppm}$ resulted in a decrease the number of branches/ leaf that could indicate that auxins in high concentrations could inhibit shoot and branch growth. According to Raj et al. (2013) and Sarmiento et al. (2016), a high auxin concentration stimulates the biosynthesis of ethylene, which further triggers the production of abscisic acid (ABA). The ABA together with ethylene, accelerates leaf senescence and ultimately death of leaf. In this condition, leaf death allows leaf abortion which further leads to decreased leaf area. Likewise, the addition of coconut water with higher concentrations up to $100 \%$ inhibit the growth of leaf area due to the concentration of PGR such as cytokinin, auxins, and gibberellins contained in it will be in supra-optimal concentration (Table 3 ) thus exceeding the required PGR concentration of the plant tissue.

\section{Number and length of roots}

The effect of NAA+ CW combination on number and length of roots. Table 4 showed that in the combination treatment of $80 \% \mathrm{NAA}+20 \% \mathrm{CW}$ produced the highest root number of 42.87 with the root length of $16.55 \mathrm{~cm}$. In this combination, the increase in roots number was followed by the decrease in root length. The highest root length of $23.70 \mathrm{~cm}$ was found in $100 \%$ NAA but had the lowest root number of $7.67 \mathrm{~cm}$. This phenomenon is similar to that reported by Rahdari et al. (2014) that an increase in the number of roots in Cordilyn graft treated with auxin (IBA and NAA) is accompanied by a decrease in long growth.

Table 3. The average length of shoot and leaf area of branch cutting on the various combination of $\mathrm{NAA}+\mathrm{CW}$

\begin{tabular}{lcc}
\hline Combination of NAA + CW & $\begin{array}{c}\text { Length of shoot } \\
(\mathbf{c m})\end{array}$ & $\begin{array}{c}\text { Leaf area } \\
\left(\mathbf{c m}^{2}\right)\end{array}$ \\
\hline $100 \% \mathrm{CW}$ & $0.80 \mathrm{a}$ & $6.72 \mathrm{a}$ \\
$20 \% \mathrm{NAA}+80 \% \mathrm{CW}$ & $0.74 \mathrm{a}$ & $11.93 \mathrm{a}$ \\
$40 \% \mathrm{NAA}+60 \% \mathrm{CW}$ & $0.53 \mathrm{a}$ & $11.94 \mathrm{a}$ \\
$60 \% \mathrm{NAA}+40 \% \mathrm{CW}$ & $0.78 \mathrm{a}$ & $23.93 \mathrm{~b}$ \\
80\% NAA + 20\% CW & $1.44 \mathrm{~b}$ & $41.29 \mathrm{c}$ \\
$100 \% \mathrm{NAA}$ & $0.53 \mathrm{a}$ & $4.77 \mathrm{a}$ \\
\hline
\end{tabular}

Note: the mean followed by the same letters on the same column showed no significant difference according to DMRT 5\%.

Table 4. The average roots number and roots length of branch cutting on the various combination of $\mathrm{NAA}+\mathrm{CW}$

\begin{tabular}{lcc}
\hline Combination of NAA + CW & $\begin{array}{c}\text { Number of } \\
\text { roots }\end{array}$ & $\begin{array}{c}\text { Length of } \\
\text { roots (cm) }\end{array}$ \\
\hline $100 \% \mathrm{CW}$ & $4.47 \mathrm{a}$ & $2.99 \mathrm{a}$ \\
$20 \% \mathrm{NAA}+80 \% \mathrm{CW}$ & $13.27 \mathrm{bc}$ & $3.80 \mathrm{ab}$ \\
$40 \% \mathrm{NAA}+60 \% \mathrm{CW}$ & $15.80 \mathrm{c}$ & $6.59 \mathrm{ab}$ \\
$60 \% \mathrm{NAA}+40 \% \mathrm{CW}$ & $24.67 \mathrm{~d}$ & $8.65 \mathrm{~b}$ \\
$80 \% \mathrm{NAA}+20 \% \mathrm{CW}$ & $42.87 \mathrm{e}$ & $16.55 \mathrm{c}$ \\
$100 \% \mathrm{NAA}$ & $7.67 \mathrm{ab}$ & $23.70 \mathrm{~d}$ \\
\hline
\end{tabular}

Note: the value followed by the same letters on the same colomn show no significant difference according to DMRT $5 \%$. 
In this study, all combinations of NAA $+\mathrm{CW}$ increased the number of roots (Table 5). NAA synergize with cytokinin contained in coconut water induce of the root growth. The role of cytokinin in spurring root growth, especially by stimulating the differentiation of root meristem cells (Muller and Leyser 2011), whereas the role of auxin has been reported as the central mediator of organ development by promoting cell division, cell extension, and cell differentiation (Ditengou 2006). Auxin has proven to accelerate and improve the rooting percentage of the stem cuttings (Kasim and Rayya 2009) while cytokinin according to Jonas et al. (2012) is phytohormone that stimulates water uptake, promote cell division and organ development and auxin has the role in root initiation. Nasri et al. (2015) revealed that exogenous auxin applications may have an indirect influence by increasing the translocation rates and sugar movement to stem cuttings and promote root growth.

Table 4 also showed that the increase in NAA concentrations up to $100 \%$ lead to the decrease in roots number. It was due to the auxin required had exceeded the optimum concentration to support the root growth. Karunarathna and Haris (2016) reported that auxin induces the adventive rooting but at the high concentrations of auxin often causes damage. Hartmann et al. (1997) mentioned that the higher concentration of auxins inhibits induction and elongation of roots and stimulates plant cells to produce ethylene. Davies (1990) also reported that root growth restriction caused by high concentration of auxin is mediated by auxin-produced ethylene. It is supported by the statement of Muller and Leyser (2011) that auxin applications depend on the type and concentration, auxin can stimulate rooting, hamper the growth of shoot or produce herbicidal effects.

The combination of $80 \% \mathrm{NAA}+20 \% \mathrm{CW}$ was the best treatment in increasing the growth of yellow bamboo branching cuttings significantly on the variables of shoot emergence time, shoot length, leaf area, root number, and root length. The soaking duration did not significantly affect all variables observed, except in the shoot emergence time which showed the fastest time with soaking for $36 \mathrm{~h}$. The effect of interaction between the combination of $80 \%$ $\mathrm{NAA}+20 \% \mathrm{CW}$ with soaking duration of $36 \mathrm{~h}$ occurred on shoot emergence time.

\section{ACKNOWLEDGEMENTS}

This research was financially supported by ALG (Academic Leadership Grant) of Prof. Johan Iskandar. We take this opportunity to express our special appreciation to Prof. Tri Hanggono Achmad, a rector of the Padjadjaran University who has supported the ALG program and encouraged conduct of the research.

\section{REFERENCES}

Banik RL. 1995. A manual for vegetative propagation of bamboos. International Network for Bamboo and Rattan (INBAR), UNDP/FAO
Regional Forest Tree Improvement Project (FORTIP) and Bangladesh Forest Research Institute (BFRI).

Bhol N, Parida S. 2015. Influence of growth regulators on propagation of culm- and branch cuttings of Bambusa vulgaris. J Tree Sci. 34 (1): 64-68.

Davies PJ. 1990. The plant hormones: their nature, occurrence and functions. In. Davies PJ. (ed.). Plant Hormones and their Role in Plant Growth and Development. Kluwer, Boston.

Devi YR. 2013. Bamboo forest resources of India and its role in food security-a review. Agri Reviews 34 (3): 236-241. DOI10.5958/j.0976-0741.34.3.009.

Goyal AK, Middha SK, Usha T, Chatterjee S, Bothra AK, Nagaveni MB, Sen A. 2010. Bamboo-infoline: a database for north Bengal bamboos. Bioinformation 5 (4): 184-185.

Hartmann HT, Kester DE, Davies FT, Geneve RL. 1997. Plant Propagation: Principles and Practices. Prentice Hall International, London, UK.

Ibironke OA. 2016. Effects of rooting hormones on the propagation of bougainvillea from cuttings. Int J Res Agri Forest 3 (1): 57-62

Islam MA, Bhuiyan MK, Hossain MM, Hossain MA. 2011. Clonal propagation of Bambusa vulgaris by leafy branch cuttings. J Forest Res 22 (3): 387-392.

Jonáš M, Salaš P, Baltazár T. 2012. Effect of exogenously application selected phytohormonal substances on the physiological and morphological indicators of Philadelphus x hybrid in containers. Acta Universitatis Agriculturae Et Silviculturae Mendelianae Brunensis 12 (8): 109-118

Karunarathna B, Harris KD. 2016. Effect of coconut water on the cutting establishment of Ixora (Ixora cocciniea L.). Int J Adv Res Rev 1 (11): 27-33.

Kasim NE, Rayya A. 2009. Effect of different collection times and some treatments on rooting and chemical in terminal constituents of bitter almond hardwood cutting. J Agri Biol Sci 5 (2): 116-122.

Kaushal R, Gulabrao YA, Tewari SK, Chaturvedi S, Chaturvedi OP. 2011. Rooting behaviour and survival of bamboo species propagated through branch cuttings. Indian J Soil Conserv 39 (2): 171-175.

Khudhur SA, Omer TJ. 2015. Effect of NAA and IAA on stem cuttings of Dalbergia. J Biol Life Sci 6 (2): 208-220.

Muhammad K, Gul Z, Jamal Z, Ahmed M, Asif ur RK, Khan ZU. 2015. Effect of coconut water from different fruit maturity stages, as natural substitute for synthetic PGR in vitro potato micropropagation. Intl $\mathbf{J}$ Biosci 6 (2): 84-92.

Muller D, Leyser O. 2011. Auxin, cytokinin and the control of shoot branching. Ann Bot 107: 1203-1212.

Nasri F, Fadakar A, Saba MK, Yousefi B. 2015. Study of indole Butyric Acid (IBA) effects on cutting rooting improving some of wild genotypes of Damask roses (Rosa damascena Mill.). J Agri Sci 60 (3): 263-275.

Pandey A, Tamta S, Giri D. 2011. Role of auxin on adventitious root formation and subsequent growth of cutting raised plantlets of Ginkgo biloba L. Int J Biodvers Conserv 3 (4): 142-146

Rahdari P, Khosroabadi M, Delfani K. 2014. Effect of different concentration of plant hormones (IBA and NAA) on rooting and growth factors in root and stem cuttings of Cordyline terminalis. $\mathrm{J}$ Med Bioeng 3 (3): 190-194

Raj XJ, Ballabh B, Murugan MP, Dhar P, Tayade AB, Warhgat AR, Chaurasia OP, Srivastava RB. 2013. Eeffect of auxins on adventitious rooting from hardwood cuttings of Hippophae rhamanoides under Ladakh, Himalayas. Indian Forester, 139 (3): 228-231.

Razvi S, Nautiyal S, Bakshi M, Bhat JA, Pala NA. 2011. Influence of season and phytohormones on rooting behavior of green bamboo by cuttings. Int J Conserv Sci 2 (3): 199-206.

Sarmiento AIP, de Souza PVD, Schwarz SF. 2016. Collection season and auxin treatment in the propagation by cuttings of mandarin hybrids. Pesq Agropec Trop Goiânia 46 (2): 215-221.

Tiwari RKS, Das K. 2010. Effect of stem cuttings and hormonal pretreatment on propagation of Embelia tsjeriam and Caesalpinia bonduc, two important medicinal plant species. J Med Plants Res 4 (15): $1577-1583$.

Wróblewska K. 2015. Benzyladenine effect on rooting and axillary shoot outgrowth of Gaura lindheimeri Engelm. A. Gray cuttings. Acta Sci Pol Hortorum Cultus 12 (3): 127-136.

Yong JWH, Ge L, Ng YF, Tan SN. 2009. The chemical composition and biological properties of coconut (Cocos nucifera $\mathrm{L}$.) water. Molecules 14 (12): 5144-5164. 
Yong WHJ, Liya G, Yan Fei N, Swee NT. 2013. The composition of plant growth regulators in coconut water. Parsons Laboratory, Department of Civil \& Environmental Engineering, MIT, Cambridge, MA 02139,
USA 3Natural Sciences \& Science Education, Nanyang Technological University, Nanyang Walk, Singapore. 